\title{
Współistnienie dyskrazji komórek plazmatycznych i zespołu mielodysplastycznego - opisy przypadków i przegląd piśmiennictwa
}

\author{
Coexistence of plasma cell dyscrasias and myelodysplastic \\ syndrome - study of cases and review of literature
}

\author{
Aleksandra Gołos ${ }^{1}$, Anna Paczek ${ }^{1}$, Ewa Lech-Marańda ${ }^{1,2}$, \\ Krzysztof Warzocha ${ }^{1}$, Joanna Góra-Tybor ${ }^{1}$ \\ ${ }^{1}$ Klinika Hematologii, Instytut Hematologii i Transfuzjologii, Warszawa \\ ${ }^{2}$ Klinika Hematologii i Transfuzjologii, Centrum Medyczne Kształcenia Podyplomowego, Warszawa
}

\begin{abstract}
Streszczenie
Wprowadzenie do praktyki klinicznej nowych terapii wptynęto na istotne wydtużenie przeżycia chorych na szpiczaka plazmocytowego (PCM). Dtuższa obserwacja pacjentów spowodowata ujawnienie odlegtych powiktań po leczeniu. Jednym z nich sq wtórne nowotwory, między innymi zespoty mielodysplastyczne (MDS) i ostre białaczki szpikowe. Znacznie rzadziej MDS może wspótistnieć z PCM od momentu diagnozy albo sie pojawić w przebiegu obserwacji u nieleczonych chorych. W artykule opisano 5 chorych: $z$ wtórnym do terapii szpiczaka plazmocytowego MDS, ze wspótistnieniem obu jednostek chorobowych od poczqtku diagnozy, z MDS poprzedzajacym o kilka lat rozpoznanie PCM oraz z gammapatia monoklonalnq o nieustalonym znaczeniu z towarzyszacym MDS.
\end{abstract}

Słowa kluczowe: szpiczak plazmocytowy, ostra białaczka szpikowa, zespół mielodysplastyczny

Hematologia 2017; 8, 2: 144-151

\begin{abstract}
The improvement in plasma cell myeloma (PCM) treatment and much longer overall survival of the patients led to the observation of long-term complications of the therapy. These include secondary malignancies, such as myelodysplastic syndromes (MDS) and acute myeloid leukemia. Definitely less common is the co-occurrence of MDS at the point of diagnosis of PCM or MDS evolving during the observation of untreated patients with monoclonal gammapathy of undetermined significance. In the article we describe 5 patients: one with a therapy-related MDS, the co-occurrence of both diseases from the diagnosis and MDS preceding PCM for several years.
\end{abstract}

Key words: plasma cell myeloma, acute myeloid leukemia, myelodysplastic syndrome

Hematologia 2017; 8, 2: 144-151

Adres do korespondencji: Aleksandra Gołos, Klinika Hematologii, Instytut Hematologii i Transfuzjologii, ul. Indiry Gandhi 14, 02-776 Warszawa, e-mail: agolos@ihit.waw.pl 


\section{Wprowadzenie}

Przed pojawieniem się w leczeniu chorych na szpiczaka plazmocytowego (PCM, plasma cell myeloma) leków alkilujących całkowite przeżycie (OS, overall survival) chorych nie przekraczało roku [1]. Wprowadzenie kolejnych nowych grup leków spowodowało znaczne przedłużenie OS, którego mediana obecnie wynosi 5-7 lat [2]. Zmiana naturalnego przebiegu choroby spowodowała zwiększenie częstości rozpoznań wtórnych nowotworów, zwłaszcza zespołów mielodysplastycznych (MDS, myelodysplastic syndrome) i ostrej białaczki szpikowej (AML, acute myeloid leukemia).

Występowanie nowotworów układu krwiotwórczego jest najczęściej wtórne do wcześniejszej chemioterapii, przede wszystkim obejmującej leki alkilujące. Pierwsze opisy przypadków sugerujących związek przyczynowo-skutkowy między wcześniejszym leczeniem melfalanem w przebiegu PCM i rozwojem wtórnej AML opublikowali Kyle i wsp. w 1970 roku [3]. Obserwacje te potwierdzili inni autorzy [4]. W ostatnich latach jest podnoszony również problem zwiększonego ryzyka MDS/AML u chorych otrzymujących leki immunomodulujące (IMID, immunomodulating drugs) [5]. W metaanalizie Mailankody i wsp. [5], obejmującej 3218 chorych na PCM leczonych w latach 2000-2012, wykazano, że 5-letnie skumulowane ryzyko wtórnych MDS/AML było istotnie wyższe w grupie pacjentów otrzymujących lenalidomid $(3,1 \%$ v. 1,4\%), (95-proc. przedział ufności [CI, confidence interval $1,15-12,6 ; \mathrm{p}=0,03)$. Natomiast $\mathrm{w}$ prospektywnym, wieloośrodkowym badaniu obserwacyjnym Connect $\mathrm{MM}^{\circledR}$ nie wykazano zwiększonej częstości wtórnych nowotworów u chorych leczonych lenalidomidem [6]. Badanie objęło 1450 chorych, a średni czas obserwacji wynosił 33,5 miesiąca. Wtórne nowotwory obserwowano u $4 \%$ chorych, w tym $1,2 \%$ stanowiły nowotwory układu krwiotwórczego; 3-letnia skumulowana częstość nowotworów hematologicznych wynosiła $1,1 \%$ $\mathrm{w}$ grupie otrzymującej lenalidomid w porównaniu z 1,6\% w grupie nieprzyjmującej tego leku.

Współwystępowanie dyskrazji plazmocytowych i nowotworów układu krwiotwórczego jest opisywane również u chorych niepoddanych wcześniej terapii. W dużym badaniu populacyjnym, obejmującym 5657 pacjentów z monoklonalną gammapatią o nieustalonym znaczeniu (MGUS, monoclonal gammapathy of undetermined significance), ryzyko zachorowania na MDS/AML było 8-krotnie wyższe niż w ogólnej populacji [5]. Ze względu na stosunkowo rzadkie występowanie takiej koincy- dencji w porównaniu $z$ wtórnymi MDS w literaturze są dostępne wyłącznie opisy pojedynczych chorych lub serii przypadków [7-9]. W niniejszym artykule opisano przypadki współwystępowania MDS wtórnego do terapii PCM, PCM i MDS, MGUS i MDS, a także MDS poprzedzającego rozpoznanie PCM.

\section{Opisy przypadków}

Zespół mielodysplastyczny wtórny

do chemioterapii z powodu PCM

U 55-letniej kobiety, w kwietniu 2007 roku, rozpoznano PCM IgA lambda. Stadium zaawansowania choroby określono jako IIIA według klasyfikacji Durie-Salmona. Stężenie białka całkowitego w surowicy wynosiło $9,55 \mathrm{~g} / \mathrm{dl}$, a białka monoklonalnego - 3,6 g/dl. W badaniu radiologicznym kośćca nie wykazano zmian osteolitycznych. W badaniu histopatologicznym szpiku stwierdzono 30-procentowy naciek $z$ komórek plazmatycznych. W leczeniu pierwszej linii zastosowano 6 kursów chemioterapii według schematu VAD (winkrystyna, doksorubicyna, deksametazon), nie uzyskując remisji choroby. Następnie chora otrzymała 8 kursów według schematu PAD (bortezomib, doksorubicyna, deksametazon). Cztery ostatnie kursy podano, stosując zmniejszoną — ze względu na objawy polineuropatii obwodowej - dawkę bortezomibu. Po zastosowanym leczeniu uzyskano częściową odpowiedź (PR, partial response). Jako konsolidację podano wysokodawkowaną chemioterapię (melfalan $200 \mathrm{mg} / \mathrm{m}^{2}$ ) wspomaganą przeszczepieniem autologicznych krwiotwórczych komórek macierzystych (auto-HSCT, autologous hematopoietic stem cell transplantation), po której stwierdzono bardzo dobrą odpowiedź częściową (VGPR, very good partial response). Chora pozostawała pod obserwacją przez około 2 lata. W marcu 2011 roku zaobserwowano progresję choroby - pojawiły się zmiany osteolityczne, stężenie białka monoklonalnego wzrosło do $1,72 \mathrm{~g} / \mathrm{dl}$, a w badaniu trepanobiopsji naciek z plazmocytów stanowił 30-40\% komórek szpiku. Po zastosowaniu 6 kursów chemioterapii według schematu CTD (cyklofosfamid, talidomid, deksametazon) uzyskano całkowitą odpowiedź (CR, complete response). Po 2 latach obserwacji wystąiły niedokrwistość, wzrost stężenia białka monoklonalnego w surowicy, białko monoklonalne w moczu, a ponadto nowe zmiany osteolityczne. $\mathrm{W}$ trepanobiopsji szpiku stopień nacieku z plazmocytów wzrósł do 70\%. Chorą zakwalifikowano do leczenia piątej linii lenalidomidem $z$ deksametazonem oraz radioterapii. W trakcie leczenia obserwowano pogorszenie stanu ogólnego pacjentki i zmniejszenie 
masy ciała. W morfologii krwi obwodowej stwierdzono pancytopenię: leukocytoza (liczba krwinek białych [WBC, white blood cells]) 1,96 G/l, stężenie hemoglobiny (Hb) 6,5 g/dl, liczba płytek krwi (PLT, platelets) $32 \mathrm{G} / \mathrm{l}$ ). Łącznie podano 8 cykli leczenia, po których stwierdzono VGPR. W mielogramie obserwowano cechy dyserytropoezy i dysplazji w układzie ziarnistokrwinkowym oraz prawidłową liczbę komórek plazmatycznych. W trepanobiopsji szpiku nie dostrzeżono nacieków PCM i potwierdzono zmiany dysplastyczne. W badaniu cytogenetycznym szpiku wykazano kariotyp złożony $\mathrm{z}$ monosomią chromosomów 7, 12, 13 i 21 pary, utratą chromosomu X, trisomią 14 i 22 , addycją materiału nieznanego pochodzenia w chromosomach $5,6,12$, del 20q. Rozpoznano wtórny do leczenia MDS o podtypie cytopenii opornej na leczenie $z$ wieloliniową dysplazją (RCMD, refractory cytopenia with multilineage dysplasia). Stadium zaawansowania MDS określono jako pośrednie-2 według Międzynarodowego Systemu Prognostycznego (IPSS, International Prognostic Scoring System). Chorą zakwalifikowano do leczenia azacytydyną. Początkowo w trakcie leczenia obserwowano trwającą 11 miesięcy stabilizację choroby (SD, stable disease). Po 9 cyklach leczenie zakończono ze względu na utratę odpowiedzi, w tym ponowną zależność od przetoczeń krwi i postępujące wyniszczenie. Wykluczono transformację do AML. Chora zmarła po 8 latach od rozpoznania PCM, 3 lata po rozpoznaniu MDS.

\section{Zespół mielodysplastyczny}

w przebiegu tlącego się PCM

U dotychczas zdrowej 72-letniej kobiety rozpoznano tlący się PCM (SMM, smouldering multiple myeloma) typu IgG kappa. W chwili rozpoznania stężenie białka monoklonalnego wynosiło $2,1 \mathrm{~g} /$ /dl; nie stwierdzono cech uszkodzenia narządowego ani objawów CRAB (calcium [podwyższenie stężenia wapnia w surowicy], renal insufficiency (niewydolność nerek; stężenie kreatyniny $>2,0 \mathrm{mg} / \mathrm{dl}$ ], anemia [niedokrwistość; stężenie $\mathrm{Hb}<10 \mathrm{~g} / \mathrm{dl}$ ], bones [ubytki osteolityczne w kośćcu lub osteoporoza ze złamaniami kompresyjnymi]). W trepanobiopsji szpiku odsetek komórek plazmatycznych wynosił $10 \%$ wszystkich komórek, innych patologii nie wykazano. Chora pozostawała pod obserwacją. Po 7 latach w morfologii krwi obwodowej obserwowano pancytopenię: liczbę WBC 1,4 G/l, stężenie Hb 10,6 g/dl, liczbę PLT 84 G/l. $\mathrm{W}$ mielogramie nie stwierdzono progresji SMM, natomiast opisano cechy dysplazji; mieloblasty stanowiły $2,8 \%$, a plazmocyty $-3 \%$ wszystkich komórek. W trepanobiopsji szpiku odsetek plazmo- cytów wzrósł do 20-25\%, ponadto występowały cechy trójliniowej dysplazji, bez wzrostu odsetka blastów. W badaniu cytogenetycznym szpiku wykazano złożony kariotyp $z$ obecnością delecji (11q21q23), delecji (5)(q31q35), addycji (9)(q22) i addycji (12)(p11.2). Rozpoznano MDS o podtypie RCMD i ryzyku pośrednim-2 według IPSS. Chorą zakwalifikowano do leczenia azacytydyną. Dotychczas pacjentka otrzymała 16 kursów leczenia; uzyskano stabilizację parametrów morfologii krwi, nie występują cechy progresji PCM.

\section{Jednoczasowe rozpoznanie MGUS i MDS}

Kobieta w wieku 75 lat została przyjęta do kliniki hematologii w celu przeprowadzenia diagnostyki niedokrwistości makrocytarnej, którą stwierdzono podczas wykonywanych rutynowo badań kontrolnych. Parametry morfologii krwi obwodowej były następujące: liczba WBC 3,87 G/l, stężenie $\mathrm{Hb} 7,3 \mathrm{~g} / \mathrm{dl}$, średnia objętość krwinki (MCV, mean corpuscular volume) $124 \mathrm{fl}$, średnia zawartość hemoglobiny ( $\mathrm{MCH}$, mean cell hemoglobin) 40,6 pg, średnie stężenie hemoglobiny w krwince (MCHC, mean cell hemoglobin concentration) 32,6 g/dl, liczba PLT 189 G/l. Wykluczono niedoborowe przyczyny niedokrwistości i hemolizę. $\mathrm{W}$ badaniach biochemicznych stwierdzono podwyższone stężenia białka monoklonalnego $(1,59 \mathrm{~g} / \mathrm{dl})$ oraz $\beta_{2}$-mikroglobuliny (3,09 mg/l). W badaniu immunofiksacji surowicy krwi potwierdzono obecność białka monoklonalnego klasy IgG lambda oraz nieprawidłowy stosunek kappa/lambda wynoszący 0,09 . W immunofiksacji moczu wykryto wolne łańcuchy typu lambda. Nie stwierdzono zmian osteolitycznych. W mielogramie opisano zwiększony odsetek komórek blastycznych (do 8\%) oraz plazmocytów (do $8 \%$ ). W badaniu histopatologicznym szpiku komórki blastyczne stanowiły około $5 \%$ wszystkich komórek, plazmocyty $-4 \%$, a ponadto były obecne cechy trójliniowej dysplazji. W badaniu cytogenetycznym szpiku wykazano złożony kariotyp $z$ obecnością trzech monosomii chromosomów 11, 19 i 21 pary. Rozpoznano MGUS ze wspólistnieniem MDS typu opornej niedokrwistości z nadmiarem blastów 1 (RAEB-1, (refractory anemia with excess of blasts 1) o ryzyku pośrednim-2 według IPSS. Chorą zakwalifikowano do leczenia azacytydyną. W ocenie po 16 kursach leczenia stwierdzono poprawę hematologiczną - uniezależnienie od przetoczeń. W ocenie MGUS stwierdzono transformację do SMM, w tym wzrost odsetka plazmocytów do $20 \%$ komórek szpiku i zwiększenie stężenia białka monoklonalnego (bez objawów CRAB). Pacjentka kontynuuje leczenie azacytydną. 
Jednoczasowe rozpoznanie PCM i MDS

U 68-letniej chorej w 2010 roku rozpoznano PCM IgG kappa. W morfologii krwi stwierdzono pancytopenię (liczba WBC 1,27 G/l, stężenie $\mathrm{Hb}$ 8,3 g/dl, liczba PLT $109 \mathrm{G} / \mathrm{l}$ ), natomiast w surowicy krwi wykryto białko monoklonalne IgG kappa w stężeniu $2,4 \mathrm{~g} / \mathrm{dl}$. W trepanobiopsji szpiku opisano $10-15 \%$ plazmocytów oraz cechy trójliniowej dysplazji $z$ odsetkiem komórek blastycznych wynoszącym $1 \%$ wszystkich komórek. W badaniu cytogenetycznym szpiku kostnego stwierdzono prawidłowy kariotyp żeński. Na podstawie wykonanych badań rozpoznano PCM w stadium IIA według Durie-Salmona. Pacjentkę zakwalifikowano do leczenia według schematu talidomid-deksametazon, wspomagająco stosowano czynnik stymulujący tworzenie kolonii granulocytów (G-CSF, granulocyte colony-stimulating factor) oraz darbepoetynę. Ze względu na ciężkie powikłania infekcyjne, począwszy od trzeciego cyklu leczenia stosowano wyłącznie deksametazon (łącznie 6 cykli). W ocenie hematologicznej nie stwierdzono cech progresji PCM i utrzymywanie się cech trójliniowej dysplazji w trepanobiopsji szpiku. Obraz odpowiadał rozpoznaniu MDS typu RCMD. Pacjentkę zakwalifikowano do leczenia objawowego.

\section{Zespół mielodysplastyczny poprzedzający rozpoznanie PCM}

U 49-letniego chorego w 1999 roku rozpoznano MDS pod postacią opornej na leczenie niedokrwistości (RA, refractory anemia). Chory pozostawał pod obserwacją; okresowo wymagal przetoczeń koncentratu krwinek czerwonych (kkcz). W latach 2006-2012 pacjent nie zgłaszał się do poradni. Ze względu na wystąpienie dolegliwości bólowych kręgosłupa w 2012 roku wykonano u niego badanie radiologiczne kręgosłupa lędźwiowego, w którym opisano liczne ogniska osteolityczne oraz złamania kompresyjne kręgów. Chorego skierowano do kliniki hematologii $z$ podejrzeniem PCM. W morfologii krwi obwodowej stwierdzono: liczbę WBC 5,3 G/1, stężenie Hb 8,5 g/dl, liczbę PLT 149 G/l. $\mathrm{W}$ badaniach biochemicznych wykazano hiperkalcemię i stężenie białka całkowitego równe 11,5 g/ /dl; w badaniu immunofiksacyjnym surowicy krwi i moczu wykryto białko monoklonalne klasy IgG kappa, stosunek wolnych łańcuchów lekkich typu kappa/lambda wynosił 58,4, stężenie $\beta_{2}$-mikroglobuliny $-5,61 \mathrm{mg} / \mathrm{l}$, a aktywność endogennej erytropoetyny $-40 \mathrm{jm} . / \mathrm{l}$. W mielogramie opisano 23,5\% plazmocytów. W trepanobiopsji szpiku kostnego stwierdzono 50-procentowy naciek PCM oraz cechy dyserytropoezy. Na podstawie wykonanych badań dodatkowych rozpoznano PCM IgG kappa, w stadium IIIA według Durie-Salmona i III według IPSS, oraz MDS o podtypie RA. Ze względu na liczne obciążenia pacjenta zakwalifikowano do leczenia cyklofosfamidem i deksametazonem; łącznie otrzymał 6 cykli. Jako leczenie wspomagające stosowano darbepoetynę oraz kontynuowano terapię bisfosfonianami. W ocenie hematologicznej przeprowadzonej w lutym 2014 roku stwierdzono SD i rozpoczęto leczenie według schematu MPT (melfalan, prednizon, talidomid), jednocześnie kontynuując leczenie wspomagające. Do listopada 2014 roku podano 6 cykli, po których uzyskano $\mathrm{PR} z$ jednoczesnym pogłębieniem stopnia niedokrwistości. Wykluczono niedoborowe przyczyny niedokrwistości i poszerzono diagnostykę MDS: $\mathrm{w}$ trepanobiopsji nacieki PCM stanowiły około $20 \%$ wszystkich komórek, w linii czerwonokrwinkowej stwierdzono cechy dyserytropoezy, komórki blastyczne stanowiły poniżej $1 \%$ wszystkich komórek. W badaniu cytogenetycznym stwierdzono prawidłowy kariotyp męski. Na podstawie obrazu mikroskopowego rozpoznano MDS typu RA towarzyszący PCM. Do września 2016 roku pacjent pozostawał pod opieką ambulatoryjną, kontynuowano u niego leczenie wspomagające, nie wymagał przetoczeń krwi. Po kilku miesiącach ponownie obserwowano pogłębienie stopnia niedokrwistości. Powtórzono trepanobiopsję szpiku, w której stwierdzono około 70-procentowy naciek PCM. Rozpoznano progresję choroby, rozpoczęto leczenie trzeciej linii według schematu VD (bortezomib, deksametazon). Dotychczas pacjent otrzymał 2 cykle leczenia.

\section{Dyskusja}

Szpiczak plazmocytowy jest drugim pod względem częstości występowania nowotworem hematologicznym [10]. W ostatnich latach odsetek uzyskiwanych odpowiedzi i OS znacząco się zwiększyły. Doskonalenie metod terapii, wprowadzanie nowych leków oraz wydłużanie się czasu przeżycia chorych skutkuje obserwacjami częstszego występowania u pacjentów z PCM wtórnych nowotworów, w tym również MDS i AML [5].

Lekami o największym potencjale leukemogennym są leki alkilujące. Częstość występowania MDS/AML u chorych leczonych melfalanem wynosi około $3 \%$ po 5 latach od zakończenia terapii i $25 \%$ po 10 latach [11]. W analizie przeprowadzonej przez Bergsagel i wsp. [12] potwierdzono zwiększone ryzyko rozwoju wtórnej AML u pacjentów leczonych wcześniej lekami alkilującymi. W badaniu wzięło udział ponad 300 chorych na PCM otrzymujących 
schematy zawierające melfalan, cyklofosfamid, karmustynę i prednizon. Porównywano skuteczność schematu MP (melfalan, prednizon) i schematu czterolekowego; 4-letnie ryzyko rozwoju AML oszacowano na $17 \%$ w całej grupie, a częstość występowania AML nie różniła się istotnie między grupami [13]. Wyniki kolejnych badań były zbieżne z pierwszymi obserwacjami $[14,15]$. W badaniu Cuzick i wsp. [15] analizowano 648 chorych na PCM. Chorzy zostali poddani randomizacji do dwóch grup, w tym leczonych melfalanem i cyklofosfamidem. Łącznie szacowane 5-letnie ryzyko wystąpienia MDS/AML wynosiło $3 \%$, natomiast 8-letnie $-10 \%$. W grupie otrzymującej melfalan najsilniejszym czynnikiem ryzyka wystąpienia wtórnego MDS/AML była dawka leku ( $\mathrm{p}=0,0001)$. Oszacowano, że w 10-letniej obserwacji ryzyko wtórnego MDS/AML wynosi $3 \%$ na każdy rok leczenia melfalanem i jest najwyższe w pierwszych 3 latach po zakończeniu leczenia. Nie wykazano związku z czasem leczenia cyklofosfamidem ani występowaniem MDS/AML [15].

Wprowadzenie do leczenia chorych na PCM wysokodawkowanej chemioterapii wspomaganej auto-HSCT znacznie wydłużyło OS [16]. Jednocześnie dłuższa obserwacja umożliwiła analizę odległych powikłań, w tym między innymi częstszego występowania wtórnych MDS/AML. Pierwsze analizy opublikowali jeszcze w latach 90. XX wieku Govindarajan i wsp. [17]. Spośród 188 chorych poddanych auto-HSCT wyodrębniono dwie grupy - pierwszą, $z$ medianą czasu terapii lekami alkilującymi przed auto-HSCT wynoszącą 7,4 miesiąca oraz drugą, w której okres ten wynosił 24 miesiące. W grupie, która dłużej otrzymywała leki alkilujące, u 7 pacjentów doszło do rozwoju MDS. Autorzy konkludują, że w analizie czynników ryzyka wystąpienia wtórnego MDS bardziej niż wielkość dawki istotny jest okres terapii lekami alkilującymi [17]. W innym badaniu, obejmującym 3077 chorych na PCM poddanych auto-HSCT, szacowane ryzyko rozwoju wtórnego MDS/AML wynosiło około $1 \%$ [18]. Oceniano również seryjnie wykonywane badania cytogenetyczne szpiku po auto-HSCT. U $6 \%$ chorych wykryto zaburzenia cytogenetyczne związane $z$ MDS, najczęściej del20, $-7 / 7 \mathrm{q}-, \mathrm{t}(1 ; 7)(\mathrm{q} 10 ; \mathrm{p} 10)$ i -5/5q-. U części chorych zaburzenia te były przejściowe, co może tłumaczyć mniejszą częstość klinicznie jawnego MDS $\mathrm{w}$ porównaniu $z$ częstością występowania aberracji cytogenetycznych. Najważniejszymi czynnikami determinującymi występowanie zaburzeń cytogenetycznych były: liczba przeszczepionych komórek CD34+ poniżej $3 \times 10^{6} / \mathrm{kg}$ mc., wiek powyżej 70 lat, czas od diagnozy PCM do przeprowadzenia auto-HSCT przekraczający 30 miesięcy [18].

$\mathrm{W}$ analizie wtórnych do terapii MDS/AML przeprowadzonej przez Pemmaraju i wsp. [19], obejmującej 1386 chorych leczonych w latach 1993-2011, u 3,4\% zdiagnozowano wtórne do terapii (w kolejności częstości występowania) MDS, AML i przewlekłą białaczkę mielomonocytową (CMML, chronic myelomonocytic leukemia). U około $40 \%$ chorych wykonano auto-HSCT. Średni czas od diagnozy do wystąpienia wtórnego nowotworu wynosił 7 lat. W większości przypadków stwierdzono złożony kariotyp albo zmiany cytogenetyczne o wysokim ryzyku (78,8\% w MDS, $81,8 \%$ w AML i 33,3\% w CMML). Najczęściej stwierdzano aberracje chromosomów 5 i 7. Mediana OS u pacjentów $z$ wtórnym nowotworem hematologicznym wynosiła 6,3 miesiąca.

Dane dotyczące kancerogennego wpływu nowych leków w terapii PCM, IMID i inhibitorów proteasomu, są niepełne ze względu na stosunkowo krótki czas ich stosowania w terapii PCM. Istnieją doniesienia o zwiększonej częstości występowania MDS i AML po leczeniu lenalidomidem [20, 21]. Usmani i wsp. [21] oceniali trzy grupy pacjenów - leczonych talidomidem $(\mathrm{n}=668)$, leczonych talidomidem $\mathrm{z}$ bortezomibem $(\mathrm{n}=303)$ oraz leczonych lenalidomidem $z$ bortezomibem $(n=177)$ - pod względem częstości występowania wtórnych MDS i AML. U 11\% chorych stwierdzono zmiany w kariotypie charakterystyczne dla MDS, u 3\% - klinicznie jawny MDS. U połowy chorych obecność aberracji chromosomalnych wyprzedzała rozpoznanie MDS o co najmniej 6 miesięcy. Czynnikami ryzyka rozwoju mielodysplazji były stosowanie lenalidomidu, wiek powyżej 65 lat, płeć męska, stężenie $\beta_{2}$-mikroglobuliny przekraczające $5,5 \mathrm{mg} / \mathrm{dl}$ i liczne wznowy PCM w wywiadzie.

W artykule opublikowanym na łamach „Hematologii” w 2016 roku przedstawiono opis przypadku chorego $z$ PCM, u którego po roku rozpoznano MDS 5q- [22]. Chory początkowo nie wymagal leczenia PCM, następnie otrzymał 3 cykle chemioterapii według schematu CTD (cyklofosfamid, talidomid, deksametazon). Leczenie zostało przerwane ze względu na wystąpienie polineuropatii i utrzymywanie się głębokiej niedokrwistości wymagającej przetoczeń. W wyniku dalszej diagnostyki w badaniu szpiku, oprócz nacieku komórek plazmatycznych stanowiącego 15-20\% wszystkich komórek, opisano zmiany dysplastyczne w liniach erytroidalnej i megakariocytarnej. W badaniu cytogenetycznym szpiku we wszystkich analizowanych metafazach stwierdzono delecję fragmentu 
ramienia długiego chromosomu 5 pary, del(5) (q22q34), jako jedyną zmianę w kariotypie [22]. W leczeniu zastosowano lenalidomid, który pozwolił uzyskać częściową remisję cytogenetyczną MDS i częściową remisję PCM. Dokładne określenie charakteru MDS (współwystępujący od początku PCM $v$. wtórny do terapii) nie jest możliwe. Należy jednak przypuszczać, że w tym przypadku bardziej prawdopodobne jest współwystępowanie obu nowotworów niż wtórny charakter MDS po 3 cyklach leczenia CTD.

U opisanej przez autorów niniejszej pracy pacjentki (przypadek 1.) do rozwoju MDS doszło po 6 latach od rozpoznania PCM, 4 lata po auto-HSCT. Chora otrzymała 5 linii chemioterapii. W leczeniu stosowano zarówno leki alkilujące (cyklofosfamid, melfalan), jak i IMID (talidomid, lenalidomid). W przedstawionych opisach przypadków 3 chorych (80\%) miało złożony kariotyp i MDS o ryzyku pośrednim-2 według IPSS. Wszyscy otrzymali leczenie azacytydną. W pierwszym przypadku czas przeżycia chorej od rozpoczęcia terapii demetylującej wyniósł 11 miesięcy, a w kolejnych (przypadki 2. i 3.) obserwowano SD; pacjenci w chwili zakończenia obserwacji nadal byli leczeni azacytydyną, a czasy przeżycia od momentu rozpoczęcia terapii wynosily, odpowiednio, 20 i 19 miesięcy. Mediana OS w grupie chorych opisywanych przez Pemmaraju i wsp. [19] wyniosła zaledwie 6,3 miesiąca; $70 \%$ chorych otrzymało klasyczną chemioterapię. Różnica w zakresie OS w obu tych grupach może sugerować istotną rolę mechanizmów epigenetycznych w rozwoju i leczeniu chorych na MDS/AML.

Opisywane jest również częstsze występowanie nowotworów układu krwiotwórczego u nieleczonych chorych $z$ dyskrazjami komórek plazmatycznych [5]. W analizie Mailankody i wsp. [5] wykazano, że w grupie chorych z MGUS ryzyko zachorowania na MDS/AML było 8-krotnie wyższe niż w populacji ogólnej. Do rozwoju MDS/AML doszło wyłącznie w MGUS nie-IgM i było ono istotnie częstsze przy stężeniu białka monoklonalnego przekraczającym $1,5 \mathrm{~g} / \mathrm{dl}$. W innym badaniu populacyjnym oceniano ryzyko wystąpienia MDS/AML u 605 chorych z MGUS i 16710 zdrowych osób [23]. Ryzyko rozwoju MDS było istotnie wyższe w grupie MGUS w porównaniu $z$ grupą kontrolną (ryzyko względne [RR, relative risk] 2,4). Ryzyko wystapienia AML było nieznacznie zwiększone (RR 1,36). W innej analizie u 16 spośród 80 nieleczonych pacjentów z MGUS i SMM stwierdzono zmiany dysplastyczne w trepanobioptacie szpiku [24].

Największą grupę pacjentów ze wspólistnieniem dyskrazji komórek plazmatycznych i MDS opisali Copplestone i wsp. [7]. Spośród 20 chorych u 8 rozpoznano PCM, 3 MGUS, a u $1-$ SMM. W większości przypadków jako współistniejący MDS rozpoznano RA. Yoshida i wsp. [8] opisali 14 chorych - u 12 z nich rozpoznano MGUS, a u 2 SMM; wśród podtypów MDS najczęściej stwierdzano podtyp RCMD. W badanej grupie tylko jeden pacjent był obciążony niekorzystnym ryzykiem według IPSS [25], w pozostałych przypadkach stwierdzono ryzyko pośrednie-1 lub niskie.

Przyczyna współwystępowania dyskrazji plazmocytowych i nowotworów układu krwiotwórczego nie jest jasna. Podnosi się udział metylacji genów biorących udział w regulowaniu apoptozy i cyklu komórkowego (DAPK-1, death-associated protein kinase 1 i $C D K N 2 B$, cyclin-dependent kinase inhibitor 2B) [26]. Mutacja TP53 jest równiez opisywana w obu nowotworach [26]. Jej częstość szacuje się na $5-10 \%$ we wczesnych stadiach MDS i PCM i w obu chorobach jest czynnikiem pogarszającym rokowanie [26]. Wzrastająca częstość tej mutacji w bardziej zaawansowanych stadiach MDS i PCM sugeruje jej istotne znaczenie w progresji choroby, jednak opisane aberracje stanowią niewielki odsetek mutacji występujących w MDS i PCM. Większość stwierdzanych mutacji jest różna w przypadku obu nowotworów, co sugeruje ich różne podłoże genetyczne [26].

Jedną $z$ hipotez wyjaśniających powstawanie wtórnych do terapii MDS/AML jest hipoteza o klonalnej hematopoezie obecnej przy rozpoznaniu pierwotnego nowotworu [27]. Mutacje w genach DNMT3A, TET2 czy ASXL1 opisywano w próbkach krwi zdrowych ochotników i określono mianem klonalnej hematopoezy o nieustalonym znaczeniu (CHIP, clonal hemopoiesis of indeterminate potential) [28-30]. Osoby, u których stwierdzono CHIP, cechowało zwiększone ryzyko rozwoju nowotworów układu krwiotwórczego [29, 31]. W analizie Takahashi i wsp. [27] przebadano próbki szpiku 14 chorych, u których rozwinął się t-MDS/AML, pobrane przed rozpoczęciem chemioterapii stosowanej $z$ powodu pierwotnego nowotworu. U 13 chorych (92\%) zidentyfikowano 29 mutacji wiodących w 16 genach. Najczęściej występowała mutacja TP53 (36\%), a następnie: TET2 (21\%), DNMT3A, IDH2, RUNX1 (14\%). W grupie kontrolnej, którą stanowiło 142 chorych po leczeniu nowotworu, ale bez rozwiniętego t-MDS/AML, również stwierdzono klonalną hematopoezę, jednak w istotnie mniejszym odsetku (30\%). Skumulowane ryzyko t-MDS/ /AML po 5 latach wynosiło odpowiednio $30 \%$ (95\% CI 16-51) w grupie badanej i 7\% (95\% CI 2-21; $\mathrm{p}=0,016) \mathrm{w}$ grupie kontrolnej. 


\section{Podsumowanie}

W dobie coraz dłuższego OS obserwowanego u chorych na PCM występowanie wtórnych nowotworów jest istotnym problemem klinicznym. Wtórny charakter nowotworu wiąże się ze złym rokowaniem niezależnie od rodzaju uprzednio zastosowanego leczenia. W obserwacji chorych $z$ dyskrazjami komórek plazmatycznych, niewymagającymi leczenia, w różnicowaniu przyczyn cytopenii w morfologii krwi należy pamiętać o możliwości współwystępowania MDS z MGUS/SMM. Rozpoznanie MDS należy również brać pod uwagę w przypadku przetrwałych cytopenii po leczeniu PCM. Bardzo istotne dla diagnozy MDS jest badanie cytogenetyczne, które często wykazuje złożony kariotyp. W przypadku rozpoznania MDS o pośrednim-2 lub wysokim ryzyku skuteczne może się okazać leczenie azacytydyną.

\section{Piśmiennictwo}

1. Osgood EE. The survival time of patients with plasmocytic myeloma. Cancer Chemother Rep. 1960; 9: 1-10, indexed in Pubmed: 13731417.

2. Pozzi S, Marcheselli L, Bari A, et al. Survival of multiple myeloma patients in the era of novel therapies confirms the improvement in patients younger than 75 years: a population-based analysis. $\mathrm{Br}$ J Haematol. 2013; 163(1): 40-46, doi: 10.1111/bjh.12465, indexed in Pubmed: 23889344.

3. Kyle RA, Pierre RV, Bayrd ED. Multiple myeloma and acute myelomonocytic leukemia. N Engl J Med. 1970; 283(21): 1121-1125, doi: 10.1056/NEJM197011192832101, indexed in Pubmed: 5273282.

4. Rosner F, Grünwald H. Multiple myeloma terminating in acute leukemia. Report of 12 cases and review of the literature. Am J Med. 1974; 57(6): 927-939, indexed in Pubmed: 4611209.

5. Mailankody S, Pfeiffer RM, Kristinsson SY, et al. Risk of acute myeloid leukemia and myelodysplastic syndromes after multiple myeloma and its precursor disease (MGUS). Blood. 2011; 118(15): 4086-4092, doi: 10.1182/blood-2011-05-355743, indexed in Pubmed: 21795746.

6. Rifkin RM, Abonour R, Shah JJ, et al. Connect $\mathrm{MM}^{\circledR}$ — the Multiple Myeloma Disease Registry: incidence of second primary malignancies in patients treated with lenalidomide. Leuk Lymphoma. 2016; 57(9): 2228-2231, doi: 10.3109/10428194.2015.1132419, indexed in Pubmed: 26766599.

7. Copplestone JA, Mufti GJ, Hamblin TJ, et al. Immunological abnormalities in myelodysplastic syndromes. II. Coexistent lymphoid or plasma cell neoplasms: a report of 20 cases unrelated to chemotherapy. Br J Haematol. 1986; 63(1): 149-159, indexed in Pubmed: 3707860.

8. Yoshida Y, Oguma S, Ohno H, et al. Co-occurrence of monoclonal gammopathy and myelodysplasia: a retrospective study of fourteen cases. Int J Hematol. 2014; 99(6): 721-725, doi: 10.1007/ /s12185-014-1570-6, indexed in Pubmed: 24687918.

9. Mufti GJ, Hamblin TJ, Clein GP, et al. Coexistent myelodysplasia and plasma cell neoplasia. Br J Haematol. 1983; 54(1): 91-96, indexed in Pubmed: 6849839.
10. Jemal A, Siegel R, Xu J, et al. Cancer statistics, 2010. CA Cancer J Clin. 2010; 60(5): 277-300, doi: 10.3322/caac.20073, indexed in Pubmed: 20610543

11. Disenzieri A, Lacy M, Greipp P. Multile myeloma. In: Greer J, Foerster J, Rodgers G. ed. Wintrob's clinical hematology. Wolters Kluwer Health/Liippincott Williams \& Wilkins, Philadelphia 2009: 2417-2418.

12. Bergsagel DE, Bailey AJ, Langley GR, et al. The chemotherapy on plasma cell myeloma and the incidence of acute leukemia. N Engl J Med. 1979; 301(14): 743-748, doi: 10.1056/ NEJM197910043011402, indexed in Pubmed: 481481.

13. Bergsagel DE, Bailey AJ, Langley GR, et al. The chemotherapy on plasma cell myeloma and the incidence of acute leukemia. N Engl J Med. 1979; 301(14): 743-748, doi: 10.1056/ NEJM197910043011402, indexed in Pubmed: 481481.

14. Greene MH, Harris EL, Gershenson DM, et al. Melphalan may be a more potent leukemogen than cyclophosphamide. Ann Intern Med. 1986; 105(3): 360-367, indexed in Pubmed: 3740675.

15. Cuzick J, Erskine S, Edelman D, et al. A comparison of the incidence of the myelodysplastic syndrome and acute myeloid leukaemia following melphalan and cyclophosphamide treatment for myelomatosis. A report to the Medical Research Council's working party on leukaemia in adults. Br J Cancer. 1987; 55(5): 523-529, indexed in Pubmed: 3300761.

16. Attal M, Harousseau JL, Stoppa AM, et al. A prospective, randomized trial of autologous bone marrow transplantation and chemotherapy in multiple myeloma. Intergroupe Français du Myélome. N Engl J Med. 1996; 335(2): 91-97, doi: 10.1056/ /NEJM199607113350204, indexed in Pubmed: 8649495.

17. Govindarajan R, Jagannath S, Flick JT, et al. Preceding standard therapy is the likely cause of MDS after autotransplants for multiple myeloma. Br J Haematol. 1996; 95(2): 349-353, indexed in Pubmed: 8904891.

18. Barlogie B, Tricot G, Haessler J, et al. Cytogenetically defined myelodysplasia after melphalan-based autotransplantation for multiple myeloma linked to poor hematopoietic stem cell mobilization: the Arkansas experience in more than 3,000 patients treated since 1989. Blood. 2008; 111(1): 94-100, doi: 10.1182/ /blood-2007-06-097444, indexed in Pubmed: 17895401.

19. Pemmaraju N, Shah D, Kantarjian H, et al. Characteristics and outcomes of patients with multiple myeloma who develop therapy-related myelodysplastic syndrome, chronic myelomonocytic leukemia, or acute myeloid leukemia. Clin Lymphoma Myeloma Leuk. 2015; 15(2): 110-114, doi: 10.1016/j.clml.2014.07.001, indexed in Pubmed: 25107338.

20. Monaghan SA, Dai L, Mapara MY, et al. Longitudinal bone marrow evaluations for myelodysplasia in patients with myeloma before and after treatment with lenalidomide. Leuk Lymphoma. 2013; 54(9): 1965-1974, doi: 10.3109/10428194.2012.755177, indexed in Pubmed: 23216269.

21. Usmani SZ, Sexton R, Hoering A, et al. Second malignancies in total therapy 2 and 3 for newly diagnosed multiple myeloma: influence of thalidomide and lenalidomide during maintenance. Blood. 2012; 120(8): 1597-1600, doi: 10.1182/blood-2012-04-421883, indexed in Pubmed: 22674807.

22. Malenda A, Kołkowska-Leśniak A, Szumera-Ciećkiewicz A, et al. Skuteczność lenalidomidu u chorego na szpiczaka plazmocytowego wspólistniejącego $\mathrm{z}$ zespołem mielodysplastycznym związanym $\mathrm{z}$ izolowaną delecją chromosomu $5 \mathrm{q}-$. Hematologia. 2016; 7(1): 77-84, doi: 10.5603/hem.2016.0006.

23. Roeker LE, Larson DR, Kyle RA, et al. Risk of acute leukemia and myelodysplastic syndromes in patients with monoclonal gammo- 
pathy of undetermined significance (MGUS): a population-based study of 17,315 patients. Leukemia. 2013; 27(6): 1391-1393, doi: 10.1038/leu.2013.34, indexed in Pubmed: 23380709.

24. Korde N, Kristinsson SY, Landgren O. Monoclonal gammopathy of undetermined significance (MGUS) and smoldering multiple myeloma (SMM): novel biological insights and development of early treatment strategies. Blood. 2011; 117(21): 5573-5581, doi: 10.1182/blood-2011-01-270140, indexed in Pubmed: 21441462.

25. Greenberg PL, Tuechler H, Schanz J. Revised international prognostic scoring system for myelodysplastic syndromes. Blood. 2012; 120(12): 2454-2465, doi: 10.1182/blood-2012-03-420489, indexed in Pubmed: 22740453.

26. Nolte F, Mossner M, Jann JC, et al. Concomitant MDS with isolated $5 \mathrm{q}$ deletion and MGUS: case report and review of molecular aspects. Eur J Haematol. 2017; 98(3): 302-310, doi: 10.1111/ /ejh.12827, indexed in Pubmed: 27862375.

27. Takahashi K, Wang F, Kantarjian H, et al. Preleukaemic clonal haemopoiesis and risk of therapy-related myeloid neoplasms: a case-control study. Lancet Oncol. 2017; 18(1): 100-111, doi: 10.1016/S1470-2045(16)30626-X, indexed in Pubmed: 27923552.

28. Busque L, Patel JP, Figueroa ME, et al. Recurrent somatic TET2 mutations in normal elderly individuals with clonal hematopoiesis. Nat Genet. 2012; 44(11): 1179-1181, doi: 10.1038/ng.2413, indexed in Pubmed: 23001125.

29. Jaiswal S, Fontanillas P, Flannick J, et al. Age-related clonal hematopoiesis associated with adverse outcomes. N Engl J Med. 2014; 371(26): 2488-2498, doi: 10.1056/NEJMoa1408617, indexed in Pubmed: 25426837.

30. Steensma DP, Bejar R, Jaiswal S, et al. Clonal hematopoiesis of indeterminate potential and its distinction from myelodysplastic syndromes. Blood. 2015; 126(1): 9-16, doi: 10.1182/ /blood-2015-03-631747, indexed in Pubmed: 25931582.

31. Genovese G, Kähler AK, Handsaker RE, et al. Clonal hematopoiesis and blood-cancer risk inferred from blood DNA sequence. N Engl J Med. 2014; 371(26): 2477-2487, doi: 10.1056/NEJMoa1409405, indexed in Pubmed: 25426838. 